\title{
stuoses IBERO-AMERICANOS
}

\section{Migrantes e fantasmas: imagens e figuras de Benjamin Constant Migrants and phantoms: images and pictures of Benjamin Constant Migrantes y fantasmas: imágenes y figuras de Benjamin Constant}

\author{
Marcos Felipe de Brum Lopes*
}

\begin{abstract}
Resumo: Após o falecimento de Benjamin Constant, em 1891, sua imagem de Fundador da República foi fabricada por parte das elites política e, sobretudo, pelos positivistas brasileiros. Essa imagem heroica materializou-se em figuras que migram de suporte para suporte, em diferentes formatos e tamanhos, do privado ao público. Este texto busca analisar os significados históricos desse processo através do mapeamento das trajetórias das figuras, suas migrações, ressignificações e limites. Defende-se a ideia de que o republicanismo positivista do final do século XIX buscou gerar um observador-cidadão, um indivíduo da crença em imagens seculares e heroicas. Para isso, instrumentalizou a imagem de Benjamin Constant, projetando-o, através de sua morte, no espaço público. Assim, suas figuras são reproduzidas e circulam na imprensa, em monumentos, nas belas artes e no museu que, até hoje, preserva seus documentos e promove sua biografia. Ao final, avalia-se a importância e os limites da retomada da discussão em torno da mobilização de imagens e figuras nacionais em tempos de crise política.
\end{abstract}

Palavras-chave: fotografia; imagem; figura; República.

Abstract: After the death of Benjamin Constant in 1891, his image of Founder of the Republic was manufactured by a fraction of the political elites and, above all, by the Brazilian positivists. This heroic image materialized in pictures that migrate from place to place, in different formats and sizes, from the private to the public. This text tries to analyze the historical meanings of this process through the mapping of the trajectories of the pictures, their migrations, resignifications and limits. Positivist republicanism of the late nineteenth century sought to generate a citizen-observer, an individual of the belief in secular and heroic images. To this end, the image of Benjamin Constant was instrumentalized and projected, through his death, into the public space. Thus, his pictures circulated in the press, appeared in monuments, in the fine arts and in the museum that, to this day, preserves his documents and promotes his biography. Finally, the text evaluates the importance and limits of the resumption of the discussion around the mobilization of national images and pictures in times of political crisis.

Keywords: photography; image; picture; Republic.

Resumen: Después de la muerte de Benjamín Constant en 1891, su imagen de fundador de la República fue fabricada por una parte de las élites política y, sobre todo, por los positivistas brasileños. Esta imagen heroica se materializa en figuras que emigran de un lugar a otro, en diferentes formatos y tamaños, desde lo privado hasta lo público. Este texto trata de analizar los significados históricos de este proceso a través del mapeo de las trayectorias de las figuras, sus migraciones, resignificaciones y límites. El republicanismo positivista de finales del siglo XIX buscó generar un ciudadano-observador, un individuo de la creencia en imágenes seculares y heroicas. Con este fin, la imagen de Benjamín Constant fue instrumentalizada y proyectada, a través de su muerte, en el espacio público. Así, sus cuadros circulaban en la prensa, aparecieron en monumentos, en las bellas artes y en el museo que, hasta el día de hoy, conserva sus documentos y promueve su biografía. Finalmente, se evalúa la importancia y los límites de la reanudación de la discusión en torno a la movilización de imágenes y figuras nacionales en tiempos de crisis política.

Palabras clave: fotografía; imágen; figura; República.

* Pesquisador e Técnico em Assuntos Culturais do Museu Casa de Benjamin Constant, Ibram/MinC.

biographic data_dados biográficos 
Em maio de 1910, no Rio de Janeiro, Crisanto Sá de Miranda Pinto acertava os últimos detalhes do seu casamento. A cerimônia aconteceria em 23 de junho daquele ano, e restavam algumas pendências a resolver. Uma delas arrastava-se desde 1897, e a decisão de casar-se, sobretudo a proximidade da data do enlace, fez com que redigisse uma carta cujo teor é, de fato, uma súplica. No dia 25 de maio de 1910 escreveu a Maria Joaquina Botelho de Magalhães, viúva de Benjamin Constant, as seguintes palavras:

Venerada Senhora. Ha alguns dias fui a vossa casa, não tendo logrado a satisfação de encontrar-vos. (...) O movel dessa insistencia, tanto mais insolita quanto não tive a honra de vos ser apresentado, é pedir-vos um retrato em grande de vosso inolvidavel Espozo, o Fundador da Republica. Em vão tenho procurado repetidamente desde 1897 essa imagem sagrada; e me ia contentando com a que acompanha o esboço biografico feito por Teixeira Mendes. Mas agora, a 23 de Junho prossimo, vou cazar-me; e redobra a minha necessidade afetiva de possuir uma digna representação da Republica, para presidir á consagração patria do meu enlace (PINTO, 1910, p. 1-2).

O noivo suplicante reafirmava sua "inquebrantável e refletida veneração" não só por Benjamin Constant, mas também pela destinatária da carta, que o abonaria a receber o retrato, além do fato de que era membro da Igreja Positivista do Brasil e seguidor da "Sublime Doutrina". Como se não bastassem essas credenciais, informava ainda que seu pedido seguia os conselhos de Teixeira Mendes, grande autoridade positivista no Brasil do fim do século XIX e primeiras décadas do século XX.

Não podemos garantir, a não ser por alguma indução, que Crisanto professava ortodoxamente a "Sublime Doutrina", como chamou o Positivismo, ou se o "viver às claras" o orientava tanto na vida privada como na pública, como ordenou Augusto Comte. Mas podemos delinear a natureza ao mesmo tempo material e sagrada de uma imagem mobilizada para afirmar sua filiação política, e construir sua performance social, documentada indiretamente na carta. Afinal, qual seria a relação entre um retrato, o enlace matrimonial, e a República?

Não vamos tratar propriamente do casamento positivista, mas sim da produção, e mobilização de artefatos visuais e como circulam entre o público e o privado. Algumas perguntas servem de base para nosso problema: como são construídas as imagens? De que forma se consubstanciam em figuras? A quem importa a sua, repetição, reprodução ou perpetuação? Como elas são ressignificadas? É possível que morram?

Artefatos visuais vinculados a imagens institucionais são bastante comuns. Pensamos, quase sempre, na pré-existência de uma instituição que, no âmbito das suas atuações, produz imagens com fins variados. E é verdade. Produzir imagens é próprio dos setores organizados das sociedades, dentre os quais se destacam as instituições. Mas é também possível que instituições sejam criadas a partir de imagens e figuras míticas, como é o nosso caso aqui. A interfertilização entre imagens e instituições, agentes institucionais e criadores de imagens que envolvem, também, consumidores, metafiguras e reprodutibilidade em mídias diversas é o objeto da nossa análise.

Nesta viagem migratória entre visual e institucional, abstrato e material, temos que assumir uma visão multifocal. $O$ foco institucional/político é a República Brasileira, o movimento positivista brasileiro, e o Museu Casa de Benjamin Constant. O foco visual é o próprio Benjamin Constant, sua imagem e suas figuras. Há também o foco na vida privada das fotografias, das figuras transformadas em metafiguras, e das pessoas que as transformaram. Vamos olhar para as imagens, figuras verbais e visuais, para ver como foram moldadas por uma vontade institucional que durou mais de um século e ainda vive numa instituição estabelecida como patrimônio nacional. Fazendo isso, poderemos também refletir sobre como essas mesmas imagens e figuras lançam de volta suas indagações, desejos, como nos olham (DIDI-HUBERMAN, 2010).

$\mathrm{O}$ percurso tem três momentos principais: em primeiro lugar, vamos explorar o papel conferido a Benjamin Constant por seus seguidores e admiradores, e como as imagens e figuras são mobilizadas no processo. O segundo momento considera a retórica visual de traço positivista, na qual a morte é trazida para o centro da vida civil republicana. Por fim, lançaremos algumas ideias sobre a veiculação das imagens expograficamente, no Museu Casa de Benjamin Constant.

\section{Como são construídas as imagens? Ou quem construiu a imagem de Benjamin Constant?}

Começamos com a primeira pergunta geral e sua versão particular, no caso em questão. Aqui vale 
lembrar que as imagens podem ser compartilhadas num sistema de valores, ou funcionar como mediadoras da comunicação sendo apenas verbalizadas, sem ter necessariamente contornos visuais. Ainda assim são imagens. Quando ganham tangibilidade, contornos e dimensões passam de imagens a figuras. Com efeito, a observação de diversos períodos e sociedades históricas atesta a existência das figuras como um tipo especial de mediadoras das imagens em geral. Essa distinção acompanha a sugestão de W. J. T. Mitchell, que distingue imagem de figura:

A figura é um objeto material, uma coisa que se pode queimar, quebrar ou rasgar. Uma imagem é o que aparece numa figura, e o que sobrevive à sua destruição - na memória, na narrativa, em cópias e rastros em outras mídias. (...) A figura, portanto, é uma imagem como esta aparece num suporte matéria ou num local específico. (MITCHELL, 2015, p. 16)

Não é o caso de descobrir quem origina quem. Nos processos históricos contemporâneos de mediação cultural nos quais o visual ocupa uma posição dialética em relação à linguagem verbal e às dimensões materiais da existência social, imagens e figuras dão vida umas às outras. Em outras palavras, o problema não é o da origem da figura (como artefato original em contraposição às cópias), mas de sua sobrevivência como suporte de uma imagem, também histórica.

A "imagem sagrada" que o noivo Crisanto buscava há 13 anos começara a ser fabricada no fim da década de 1880. Benjamin Constant era uma figura conhecida nos meios científicos da capital do império brasileiro e respeitada na área educacional, professor da Escola Normal da Corte e diretor do Imperial Instituto dos Meninos Cegos. Antes dos eventos que rodearam o 15 de Novembro de 1889 , não se pode dizer que tivesse uma verdadeira projeção pública, pois sua atuação esteve restrita ao Rio de Janeiro e aos setores escolares nos quais atuava. Um dos primeiros divulgadores da doutrina de Augusto Comte no Rio de Janeiro, Benjamin circulava também nesse grupo filosófico que se formava na Capital do Império, do qual os mais eminentes nomes viriam a ser Raymundo Teixeira Mendes e Miguel Lemos, e posteriormente Cândido Mariano da Silva Rondon, que fora aluno de Benjamin.

$\mathrm{Na}$ crise enfrentada pelo Império durante o último quarto do século XIX, Benjamin viu-se alçado ao patamar de líder de uma juventude militar entusiasmada, porém ainda inexpressiva do ponto de vista do apelo popular e da capacidade que teria para mobilizar uma revolução que fosse tão social quanto política. Ainda assim, sua defesa da República gerou os chamados Pactos de Sangue, nos quais o alunato da Escola Militar afirmava sua submissão e obediência ao que Benjamin decidisse em relação aos acontecimentos que se seguiriam ao 15 de novembro.

Nesses Pactos de Sangue, assinados dois dias depois de proclamada a República, os alunos da Escola Militar afirmavam já ver "o sol da liberdade", clamavam para que Benjamin fosse "mestre" e "interprete" de seus sentimentos, e lançavam mão de uma imagem verdadeiramente messiânica. Tal como as folhas de palmeiras levadas pela multidão ao caminho pelo qual Cristo passara em sua entrada triunfal em Jerusalém, descritas no evangelho de João, os alunos de Benjamin diziam que "flores, só flores juncam o solo puro por onde, vitorioso, haveis passado, conquistador sem rival, conduzindo um povo desgraçado à terra da promissão" (PACTO DE SANGUE, 1889).

Está aí uma primeira aproximação entre a imagem de Benjamin em vida e a representação buscada por Crisanto Sá, em 1910. Nos dois casos, Benjamin é convocado a presidir. O verbo significa tanto atuar como presidente quanto assistir, conduzindo, guiando, orientando. A imagem que se sacraliza na mobilização de alunos e positivistas é fabricada para conduzir o público e o privado, uma nação e um casamento.

Mesmo com a louvação dos discípulos e, depois, de parte da imprensa, o mestre sinalizou mais de uma vez que o homem a ser celebrado era Deodoro da Fonseca e que sua própria contribuição fora apenas convencer a "mocidade que ella devia cooperar para que a humanidade entre o mais depressa possivel no franco regimen industrial", postando-se "ao lado daqueles que prégavam a refórma politica e social de que dependiam o progresso e a ordem" da pátria brasileira (CIDADE DO RIO, 1889, p. 1).

Será que Benjamin não desejava holofotes ou ser olhado como herói? Sua militância, se podemos usar a palavra, era a ciência e a educação, e tinha o objetivo pessoal de reformar o ensino brasileiro, que levou consigo durante seus dois últimos anos de vida e que foi, de fato, sua última contribuição no serviço público. As bases gerais que pontuaram seu projeto de reforma educacional afirmavam que "o engrandecimento da República repousa essencialmente sobre a educação" (MAGALHÃES, 1890, s/p.). Muito se esforçou para isso, recusou trabalhos solicitados pelo próprio presidente Deodoro da Fonseca e meses antes de morrer conseguiu submeter o projeto de reforma do 
ensino público brasileiro. Lembrado como Ministro da Guerra do Governo Provisório, parece que o cargo que mais lhe aprouve foi o de Ministro da Instrução Pública, Correios e Telégrafos, o que vale dizer que foi o primeiro Ministro da Educação da era republicana.

Porém, a vontade individual é, não raro, sobrepujada pelo triunfo das vontades coletivas e, nesse caso, também políticas. Numa feliz convergência positivista, a vida da República brasileira seria regida por um morto. Pelo menos é o que almejou uma fração da classe política.

O título de Fundador da República, outorgado a Benjamin pelo Congresso Nacional dois dias após seu falecimento e também registrado nas Disposições Transitórias da Constituição de 1891, a primeira da era republicana, coroou o que o historiador Renato Lemos chamou de entronização de Benjamin no panteão de heróis nacionais: a criação do Clube Benjamin Constant, em 1890 em Cuiabá, o batismo de uma rua com seu nome, no Rio de Janeiro, confecção de medalhas memorativas, construção de um mausoléu para abrigo dos seus restos mortais - estas duas últimas homenagens garantidas por decreto de Deodoro, em 24 de janeiro de 1891. (LEMOS, 1999, p. 531-542) A Constituição, que confirmava tudo isso, previu o destino da última residência do homenageado:

O Governo federal adquirirá para a Nação a casa em que faleceu o Doutor Benjamin Constant Botelho de Magalhães e nela mandará colocar uma lápide em homenagem à memória do grande patriota - o fundador da República (GOVERNO PROVISÓRIO, 1891).

O trecho é precedido pela oferta do governo de uma pensão vitalícia a D. Pedro II que, "a contar de 15 de novembro de 1889, garanta-lhe, por todo o tempo de sua vida, subsistência decente" (GOVERNO PROVISÓRIO, 1891). Ao mesmo tempo em que lembra o último monarca, faz surgir a figura do fundador do regime que pôs fim ao Império.

O movimento de memória impulsionado pela elite política de então tem no projeto de Demétrio Ribeiro um bom exemplo. Submetido ao Congresso Nacional, propunha a transformação da casa de Benjamin Constant em um museu. Como o prédio fora deixado em usufruto da viúva, Maria Joaquina, situação aliás também garantida pela Carta de 1891, Demétrio Ribeiro sugeria que, após a morte de Maria Joaquina, fosse a casa "convertida em um museu de documentos de toda a sorte relativos à vida e feitos do ínclito cidadão".
Estavam em jogo fatores decisivos para a representatividade almejada pelo novo regime, ancorada em lugares e em pessoas. No caso de Benjamin Constant, ocorreram as duas coisas: foi vinculado ao patriotismo ("grande patriota"), à cidadania ("ínclito cidadão") e à trajetória dos verdadeiros heróis ("vida e feitos"); e o ambiente em que vivia e veio a falecer, sua residência de pedra e cal, ultrapassaria a função de casa, doravante ocupando uma dimensão imaginária. Surgia, construída e disputada, a imagem de Benjamin Constant. ${ }^{1}$

Retomando a distinção sugerida por Mitchell, já mencionada, podemos dizer que há uma imagem geral e heroica do Fundador da República, produzida retoricamente pelos positivistas. A dimensão imaginária consubstancia-se em figuras, visualidades registradas em suportes materiais que circulam socialmente. Não há antes e depois: as figuras podem preceder certas imagens no tempo, pois o que ocorre é, de fato, uma ressignificação das mensagens de um lado para outro. Assim, figuras de Benjamin Constant, produzidas em suportes materiais antes dos eventos que levaram a Proclamação da República, foram usadas para dar uma dimensão visual à imagem construída pelo discurso do pós-15 de novembro de 1889. As mídias que suportaram essa nova imagem foram várias: pintura, fotografia, escultura, selos postais, broches, medalhas, e o próprio museu. A imagem institucional que o Museu Casa de Benjamin Constant constrói no século XXI não pode deixar de se articular com a imagem gestada e gerida ao longo do tempo, através dessas figuras.

Os positivistas foram o grupo mais influente para a entronização de Benjamin Constant no panteão de heróis nacionais. No excelente estudo sobre arte positivista de Elisabete Leal, constatamos que os artistas Décio Villares e Eduardo de Sá contribuíram sobremaneira para a tentativa de consolidação das imagens de Benjamin, produzindo figuras do Fundador da República (LEAL, 2006). Essa imagem aparece em várias figuras e migra de suporte para suporte, em diversos momentos da história.

\footnotetext{
Como argumenta Renato Lemos, as disputas permaneceram vivas, com calmarias intermitentes, durante várias décadas. Nomes como Demétrio Ribeiro parecem ter usado a imagem de Benjamin para atacar Deodoro e sua condução do Governo Provisório. Já Quintino Bocaiúva teria provocado Deodoro projetando o falecido professor como "belo modelo de virtudes aos futuros presidentes". $\mathrm{Na}$ década de 1930, a Câmara dos Deputados não aprovou a desapropriação da casa onde nascera Benjamin pois o projeto fazia menção ao título de Fundador da República, com o que o a Comissão de Educação e Cultura não concordava (Ver: LEMOS, 1999, p. 531-542).
} 


\section{A imagem e suas figuras privadas}

As figuras de Benjamin Constant, que multiplicam visualmente sua imagem fabricada, tem um traço ao mesmo tempo sagrado e fantasmagórico. Elas sugerem uma presença dependente de uma perda, um preenchimento por um corpo que já não é. José Murilo de Carvalho, no famoso estudo sobre o movimento e os símbolos republicanos, usa a ideia de "formação das almas" para descrever o que chama de "imaginário do Brasil republicano": uma série de esforços para construir as referências identitárias e simbólicas de um regime que buscava afirmação. O que está sugerido aí é também certa carência que a fabricação retórica e visual desejava suprir, com almas. Os positivistas "constituíram, sem dúvida, o grupo mais ativo, mais beligerante, no que diz respeito à tentativa de tornar a República um regime não só aceito como também amado pela população" (CARVALHO, 1990, p. 129).

Não podemos subestimar o valor desses tipos de imagens e figuras, materializadas em fotografias, monumentos e obras de arte. Se em nossos dias eles não mobilizam mais uma alma republicana, devemos avaliar as razões históricas de seus fracassos, mas isso não significa pensar que o processo das suas fabricações já continha as sementes do malogro. Por outro lado, é claro, não se deve dançar conforme a música positivista, acreditando na coerência e unanimidade que uma leitura somente formal dessas imagens e figuras pode sugerir. Dada a função de mediação cultural que artistas e suas produções possuem numa sociedade, precisamos articular a sua versão acabada e pública com seus fragmentos passados, e retornar ao discurso público que elas propõem.

As figuras implicam um observador, as figuras de reverência civil e patriota, como as que surgem na retórica nacional positivista, requerem um observador semelhante ao "homem da crença", definido por Georges Didi-Huberman como contraponto ao "homem da tautologia". Para o filósofo francês, o ato da visão constitui-se numa cisão, num paradoxo no qual a sensação de ter corresponde à perda, a percepção de volumes é também a presença de vazios. Objetos e figuras apreendidos pela visão são constantemente levados para essa fenda do ver. Alguns deles parecem ter a função de mediar a experiência da cisão, de forma que a replicam. Didi-Huberman afirma que a função dos túmulos é exatamente operar nessa cisão:
Eis por que o túmulo, quando o vejo, me olha até o âmago - e nesse ponto, aliás, ele vem perturbar minha capacidade de vê-lo simplesmente, serenamente na medida mesmo em que me mostra que perdi esse corpo que ele recolhe em seu fundo. Ele me olha também, é claro, porque impõe em mim a imagem impossivel de ver daquilo que me fará o igual e o semelhante desse corpo em meu próprio destino futuro de corpo que em breve se esvaziará, jazerá e desaparecerá num volante mais ou menos parecido. Assim, diante da tumba, eu mesmo tombo... (DIDIHUBERMAN, 2010, p. 38).

A atitude que surge dessa experiência é um "tapar os buracos, suturar a angústia que se abre em nós diante do túmulo, e por isso mesmo nos abre em dois" (DIDI-HUBERMAN, 2010, p. 38) As duas possibilidades vislumbradas por Didi-Huberman, diante dessa cisão, são a atitude tautológica e a atitude da crença, ou seja "o primeiro seria permanecer aquém da cisão aberta pelo que nos olha no que vemos" (DIDI-HUBERMAN, 2010, p. 38). Quem opera tautologicamente aborda um objeto como objeto, e nada há além dele que possa ser experienciado ou evocado que não seja aquilo mesmo que se vê. $\mathrm{O}$ segundo meio para suturar a angústia diante da tumba consiste em querer ultrapassar a questão, "em querer dirigir-se para além da cisão aberta pelo que nos olha no que vemos". Quem operar no âmbito da crença projetará para além do objeto, e por causa dele, uma dimensão na qual a figura, a imagem, enfim, o objeto olha de volta ${ }^{2}$ (DIDI-HUBERMAN, 2010, p. 40).

$\mathrm{O}$ que nos olha, nas figuras que documentam o post-mortem de Benjamin e a formação das almas republicanas, é exatamente a tentativa da família Botelho de Magalhães de suturar a angústia da perda do patriarca, ao mesmo tempo em que os positivistas tentavam ocupar uma brecha, tapar os buracos deixados pelo fim do regime monárquico brasileiro. Por mais que, para os positivistas, fosse um tempo de uma certeza evolucionista e redentora, nos contextos privado e público é que surgem as figuras migrantes e fantasmáticas de Benjamin Constant, articuladoras de um tempo cindido, disputado e incerto.

No âmbito privado da família Botelho de Magalhães podem-se rastrear algumas figuras mi-

\footnotetext{
2 Didi-Huberman irá afirmar, num momento posterior do mesmo texto, que a imagem é a própria cisão, "uma brecha no muro, ou uma rasgadura..." (DIDI-HUBERMAN, 2010, p. 243).
} 
grantes. Em 1882 a família posou para o fotógrafo J. Insley Pacheco. ${ }^{3}$ Até aquela época, Benjamin e Maria Joaquina haviam gerado quatro filhas e um filho. Aracy Botelho de Magalhães, a caçula de toda a prole do casal, ainda não nascera. Era, ainda, uma família de sete pessoas. ${ }^{4}$ Apesar de ser um retrato do início dos anos de 1880, a atmosfera não é de todo séria. Maria Joaquina esboça um sorriso comedido, enquanto Bernardina, no colo do pai, cabeça recostada na mãe e com vestido de cor clara, deixa a cena leve. Benjaminzinho, como era chamado no seio da família, olha descontraidamente o observador da fotografia, consciente de que sua pose é um ato relacional. $\mathrm{O}$ próprio Benjamin não figura deslocado do conjunto, sente a mão de uma das filhas em seu ombro e não parece indiferente - ainda que seja o centro da fotografia - à presença dos filhos e da esposa, como é comum vermos em retratos de família oitocentista, nos quais o patriarcado dá o tom da cena (Figura 1).

Dez anos mais tarde, a família posa com a seriedade e a sisudez ausentes na fotografia de 1882 . E assim como em 1882, sete pessoas posam para o fotógrafo (Figura 2). Haveria ainda uma presença a ser contabilizada e percebida: esmaecida pela própria vida da fotografia, lá está uma sombra de Benjamin Constant, bem emoldurada, posando em frente ao filho. Essa figura de busto que pode ser a do professor, ou do Fundador da República, ou daquele homem já feito messias por seus alunos, mantém a unidade da família, que passaria a viver, em boa medida, da sua memória.

A figura de Benjamin, produzida em vida, torna-se uma metafigura de sua imagem póstuma: uma figura que ultrapassa seus próprios limites visuais e indica o funcionamento cultural de uma imagem. As metafiguras são aquelas imagens que se "aninham" no interior de outras imagens, e podem funcionar como metáfora ou analogia fundadora de um todo discursivo (MITCHELL, 2015, p. 19). As figuras de Benjamin que aparecem fantasmagoricamente dentro de outras imagens privadas e públicas mobilizam esse discurso ou esforço de sutura de uma perda (Figuras 3, 4, 5).

\footnotetext{
3 Joaquim José Pacheco (1830-1912) foi um dos principais retratistas do século XIX, no Brasil. Adotou o nome comercial Insley Pacheco na década de 1850 , no Rio de Janeiro, fazendo referência ao seu trabalho de assistente do daguerreotipista $\mathrm{H}$. E. Insley, durante o período em que atuou nos Estados Unidos da América.

${ }_{4}$ O casal teve, ao todo, cinco filhas e três filhos. Dois dos meninos, porém, faleceram ainda bebês. Portanto, apenas seis filhos alcançaram a vida adulta.
}

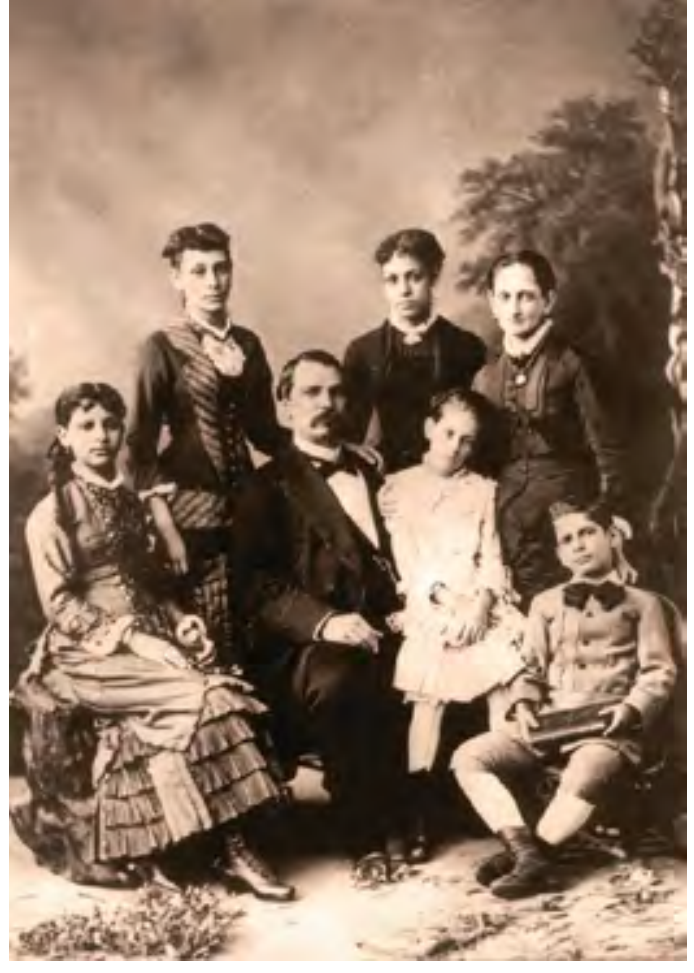

Figura 1. PACHECO, J. Insley.

Família Benjamin Constant. 1882. Carté-cabinet, albumina, fotopintura, 10,5×16,5cm, Rio de Janeiro. FBC. F.014. Museu Casa Benjamin Constant, Ibram/MinC.

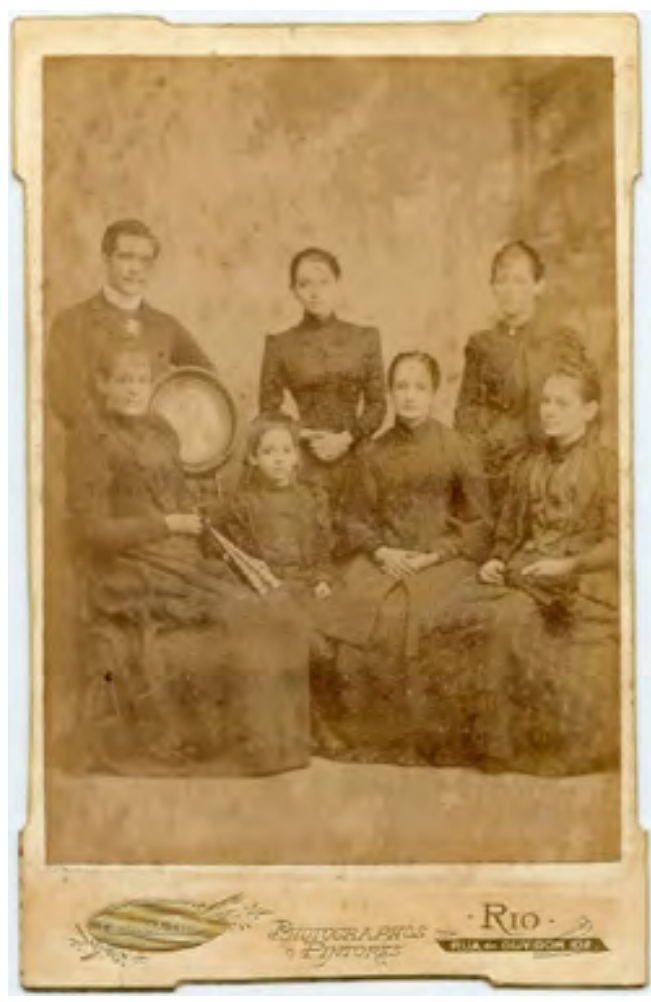

Figura 2. PACHECO E FILHO.

Família Benjamin Constant. 1892. Carté-cabinet, albumina, 10,6×16,4cm, Rio de Janeiro. FBC. F.046. Museu Casa Benjamin Constant, Ibram/MinC. 


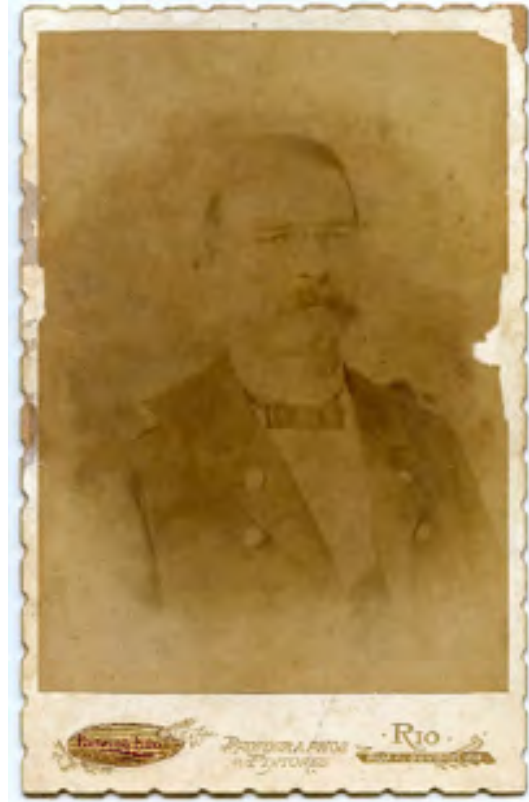

Figura 3. PACHECO E FILHO.

Benjamin Constant Botelho de Magalhães. Circa 1889. Carte-cabinêt, albumina, $10,7 \times 16,5 \mathrm{~cm}$, Rio de Janeiro. FBC. F.923. Museu Casa Benjamin Constant, Ibram/MinC.

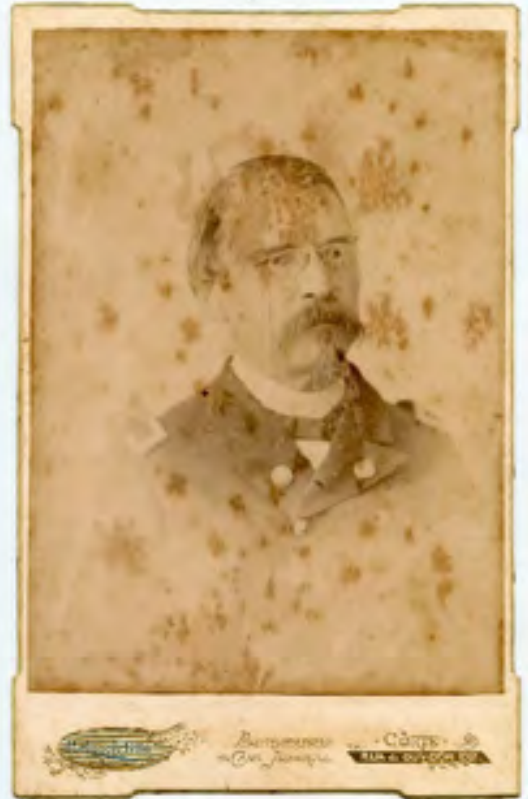

Figura 4. PACHECO E FILHO.

Benjamin Constant Botelho de Magalhães. Circa 1889. Carte-cabinêt, albumina, $10,7 \times 16,4 \mathrm{~cm}$, Rio de Janeiro. FBC. F.023.

Museu Casa Benjamin Constant, Ibram/MinC.

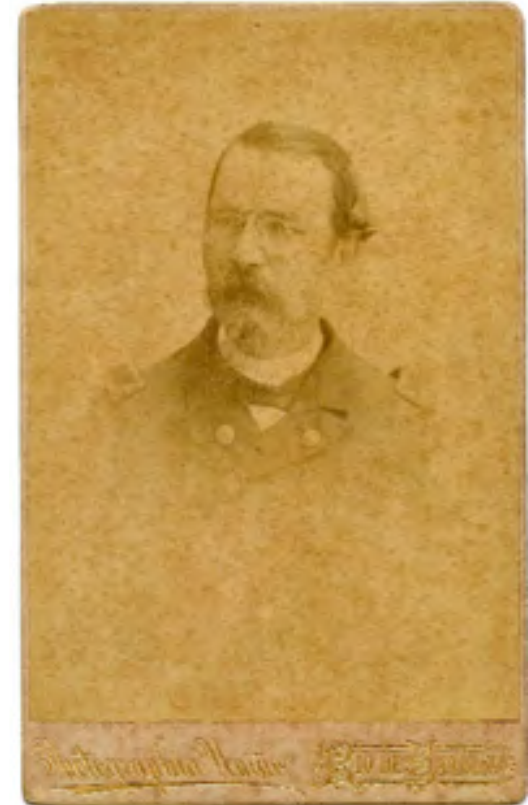

Figura 5. GUTIERREZ, Juan. (Photographia União).

Benjamin Constant Botelho de Magalhães. Circa 1890. Carte-cabinêt, albumina,

$11 \times 16,6 \mathrm{~cm}$, Rio de Janeiro. FBC. F.024.

Museu Casa Benjamin Constant, Ibram/MinC

Percorrendo o caminho das figuras, chegamos ao final da década de 1880 , quando Benjamin posou para os fotógrafos Pacheco e Juan Gutierrez. ${ }^{5}$ Além de ter recebido uma versão fotográfica colorizada pelo estúdio Valverde, dessas fotografias foram feitas várias outras figuras e objetos. Numa fotografia de 1891, já viúva, Maria Joaquina aparece tristonha, o sorriso comedido de 1882 esvaído (Figura 6). No broche, está novamente Benjamin, na foto feita por J. Gutierrez (Figura 7). Único ponto claro contra a roupa do luto, esse lugar privado em que o morto habita e no qual se reproduz a viuvez eterna positivista projeta tanto a memória do marido quanto o papel social da esposa. Maria Joaquina participou ativamente da imagem construída de seu marido,

\footnotetext{
5 Juan Gutierrez (ca. 1860-1897) é considerado um dos principais cronistas visuais da cidade do Rio de Janeiro do século XIX, ao lado de Marc Ferrez e George Leuzinger. Os empreendimentos fotográficos ligados a seu nome são a Photographia União, Companhia Photographica Brazileira e J. Gutierrez e são reconhecidas pelas belas imagens que documentam a passagem do Império à República, bem como retratos de figuras da política.
}

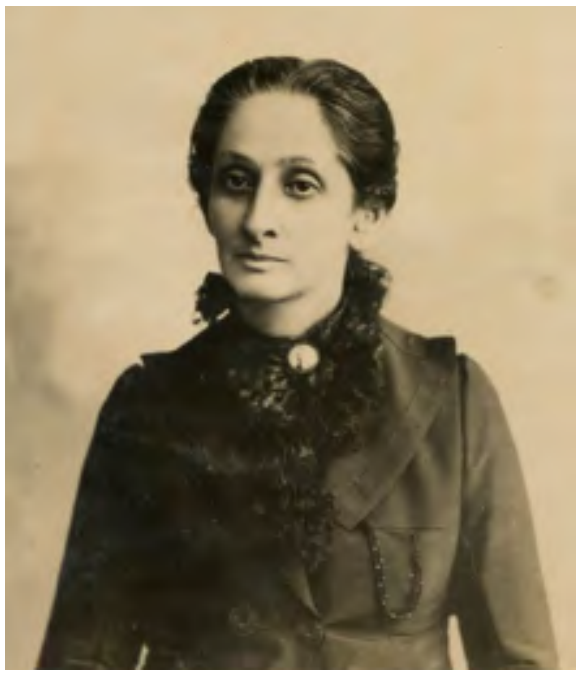

Figura 6. PACHECO, Insley. Maria Joaquina Botelho de Magalhães. Circa 1891. Gelatina de prata, $11,3 \times 16,4 \mathrm{~cm}$, Rio de Janeiro. FBC. F.045. Museu Casa Benjamin Constant, Ibram/MinC.

Figura 7. GUTIERREZ, Juan. Benjamin Constant Botelho de Magalhães.

Circa 1890. Papel fotográfico montado

em broche, $3,7 \times 2,9 \times 0,7 \mathrm{~cm}$, Rio de Janeiro. REG.654. Museu Casa Benjamin Constant, Ibram/MinC. 
não só perpetuando a presença do morto através de suas figuras, mas sendo também alçada à condição de inspiradora do Fundador da República. Enquanto viva, atuou como guardiã e mediadora da memória de Benjamin, como atesta a súplica do noivo Crisanto e tantos outros testemunhos do círculo positivista, como veremos.

\section{Repetições mecânicas, aparições fantasmagóricas}

A terceira pergunta que levantamos no princípio deste texto gira em torno da repetição, reprodução e perpetuação das figuras, e a quem interessa todo esse processo. Para que a distinção entre imagens e figuras funcione como processo social, são necessários mecanismos de migração e reaparecimento das imagens, materializadas em suportes figurativos. É assim que, a partir de poucas fotografias e pinturas pobres de variação, a imagem de Benjamin aparece e reaparece no espaço público republicano. Podese dizer que o novo regime político inaugurado em 1889 mobilizou várias personalidades heroicas que se perpetuaram na imagética oficial, ao longo do século XX e ainda atualmente.

Dois retratos pintados em óleo sobre tela por Décio Villares são recriações a partir das fotografias feitas por de Juan Gutierrez e Insley Pacheco. A fabricação dessas obras era parte de um projeto republicano, do qual participavam os recém-criados heróis nacionais, artistas, fotógrafos e jornalistas. Leitores cariocas foram informados do seguinte, em 9 de julho de 1890:

Hontem, á 1 hora da tarde, o generalíssimo Deodoro da Fonseca, acompanhado pelo distincto pintor Decio Villares e um representante da nossa folha, compareceu ao estabelecimento photographico do Sr. Gutierrez. O generalíssimo tirou o primeiro retrato em pé, tamanho natural, em grande uniforme e com todas as suas condecorações. Depois tirou sentado com o mesmo uniforme. O retrato, em tamanho natural, vae ser pintado a oleo pelo Sr. Decio Villares, porém com o fardamento que o generalíssimo compareceu no campo da Acclamação no dia 15 de Novembro, dia da proclamação da República. O benemerito Chefe do Governo emprestou ao distincto pintor aquelle fardamento (CIDADE DO RIO, 1890a, p. 1).
As fotografias de Benjamin Constant tiveram a mesma finalidade. É claro que as fotografias em carté-cabinet ou carté-de-visite serviam para outros fins que não uma projeção de poder, mas certamente fotógrafos e fotografados tinham no horizonte o uso político dessas figuras, pois rapidamente foram lançadas no espaço público da imprensa, que já preparava os leitores para a recepção da imagem. Assim, ao longo de 1890, vários retratos foram inaugurados em espaços públicos e privados brasileiros, com destaque para a comemoração no Clube Militar, em 9 de novembro de 1890 , do ultimato recebido pela monarquia da boca de Benjamin:

\begin{abstract}
Realizou-se hontem neste club uma sessão solemne comemorativa do dia 9 de novembro de 1889 , em que o dr. Benjamin Constant declarou perante crescido numero de officiaes dar uma solução definitiva no prazo de oito dias, para livrar a pátria do estado a que a havia conduzido a monarqchia. À sessão foi prezidida pelo honrado e distincto ministro da instrucção publica á convite do sr. contra-almirante Custodio José de Mello. O Dr. Benjamin pronunciou brilhante discurso, sendo ao terminar muito victoriado e coberto de flores. Foram inaugurados os retratos do generalíssimo chefe do governo e do Dr. Benjamin Constant (CIDADE DO RIO, 1890b, p. 1).
\end{abstract}

Além de Deodoro e Benjamin, pensemos nos outros dois homens que, na retórica republicana - mais mítica que unânime -, sustentou o regime. Benjamin Constant, Fundador; Deodoro da Fonseca, Proclamador; Floriano Peixoto, Consolidador; Prudente de Moraes, Pacificador. Todos eles figuram em medalhas, selos, monumentos e é difícil que livros didáticos e museus republicanos, por exemplo, possam fugir da centralidade construída dessas figuras.

O livro Quadros da História Pátria é um bom exemplo. Publicado em 1891 sob orientação de Benjamin Franklin Ramiz Galvão, então diretor da Instrução Pública do Distrito Federal, o livro é uma peça didática que oferece aos alunos do ensino público retratos (reproduções por fototipias de Marc Ferrez) e biografias das figuras históricas, desde Pedro Álvares Cabral até Benjamin Constant (que aparece na mesma fotografia que figura no broche de Maria Joaquina). Como bem observou Maria Inez Turazzi, o livro utiliza a memória como suporte de um discurso de poder que diminui a importância histórica da monarquia: 
Somente três referências indiretas a Dom Pedro II podem ser encontradas ali, pois seu nome parece ter sido deliberadamente omitido nas páginas da publicação. Os próceres republicanos não seriam vítimas do mesmo "esquecimento": o retrato fotográfico de Benjamin Constant, encerrando a publicação, indica-nos, de forma emblemática, a imediata inclusão do Fundador da República, logo após o seu falecimento, no panteão dos "grandes vultos" da história nacional (TURAZZI, 2006, p. 236).

Mas as fissuras da experiência de 1889 foram denunciadas por Eduardo Prado tão logo replicavam-se as figuras dos heróis:

Os jornais chegados nas primeiras semanas depois da pacífica epopeia, vinham todos negros de retratos, mais ou menos desenhados, formando uma série interminável de heróis, cujas feições tinham sido votadas à imortalidade de um dia, no centro da primeira página, com a prontidão que o entusiasmo requer, a nitidez que a estereotipia barata permite, e a rapidez que as condições da venda avulsa impõem. E, no texto, o jornalista, entusiasmado, explicava a gravura à nação: "Este é aquele major que viverá para sempre na história e que tinha resolvido dar a sua vida pela república, que, felizmente, não lh'a pediu! Este é aquele tenente que tão heroicamente deixou de morrer no dia 15 de novembro, mas que, não morrendo, se cobriu de glória! - Este é aquele tenente-coronel que, com jamais igualada bravura, declarou que recusava bater-se contra os regimentos revoltados!" etc., etc., etc. E a mocidade das escolas, que tão pouco estuda, aprende assim quão pouco custa e quanto rende o ser herói revolucionário (PRADO, 1890, p. 57-58).

Prado dava uma clara resposta ao discurso proferido por Benjamin Constant - a quem já havia acusado de acumular empregos no Rio de Janeiro e ensinar positivismo, enquanto seus companheiros de farda morriam na Guerra do Paraguai - no qual o professor narrava os sacrifícios que fizera no 15 de novembro. As palavras de Benjamin foram publicadas pelo cronista do Cidade do Rio, em terceira pessoa, que dava contas do "Banquete dos Livres", uma festa em homenagem ao general José Simeão, do qual participaram membros do Governo Provisório:

... acostumado a viver as claras, dirá que the foi necessário um grande esforço moral para dominar o amor a familia em nome do amor da Patria. Se o dever não tivesse tido mais força do que seu coração, confessa que não teria tido forças para separar-se de sua querida consorte e dos seus filhos, para correr ao encontro de um combate em que ele expunha estes entes queridos á penúria, ao abandono, a todas as vicissitudes da sorte de uma familia, que ficaria na viuvez e na orfandade, tendo além disso de supportar as injustiças á memoria de seu chefe, morto como um soldado rebelado (CIDADE DO RIO, 1889, p. 1).

Numa interessante manobra de um passado que não foi mas poderia ter sido, Benjamin exalta sua própria atitude de renúncia ao privado em prol do público, sim, já que Comte mesmo havia postulado que a Humanidade é maior que a Pátria, e a Pátria maior que a Família. José do Patrocínio já havia registrado, no final de 1889, que Benjamin liderara o movimento do 15 de novembro conduzindo seus seguidores com o sentimento de mártir: "Si formos vencidos, guardemos a ultima bala de nossas armas, para que nos salvemos da humilhação do aprisionamento" (PATROCÍNIO, 1889, p. 1)

Enfim, as aparentes coerências e estabilidades da República dificilmente resistem a uma análise cuidadosa dos fatos. Era um tempo de incertezas. Lembrando mais uma vez a teoria visual de W. J. T. Mitchell, "[uma] época histórica perturbadora [é] caracterizada por estranhas coincidências, repetições, duplos e fantasmas, e incertezas se os eventos são controlados por imagens fantásticas ou realistas, metáforas ou declarações literais sobre os fatos" (MITCHELL, 2015, p. 197). A clarividência e a utilidade dessa definição de Mitchell aumenta para o tema que ora analisamos, já que "narrativas de fundação nacional parecem, invariavelmente, incorporar dimensões míticas ou épicas" como repostas à perturbação histórica de um evento que é "coletivamente entendido como um divisor de águas ou um momento significativo num período histórico" (MITCHELL, 2015, p. 196).

Participantes desta retórica, os positivistas eram ferrenhos defensores da República. Seu pacifismo doutrinário não os eximia de apoiar e reproduzir as imagens e figuras dos grandes líderes do exército. ${ }^{6}$

\footnotetext{
${ }^{6}$ Note-se que o próprio Benjamin Constant, crítico que foi da Guerra do Paraguai, da qual participou a contragosto, alertava no discurso do "Banquete dos Livres": "O governo não quer senão a paz e a liberdade, a fraternidade a mais absoluta com todas as nações, mas com toda a franquesa, deve declarar que não tentem uma contra-revolução, porque o governo dispõe de meios que são mais que sufficientes para rechassar tão louca pretenção". (CIDADE DO RIO, 1889, p. 1).
} 


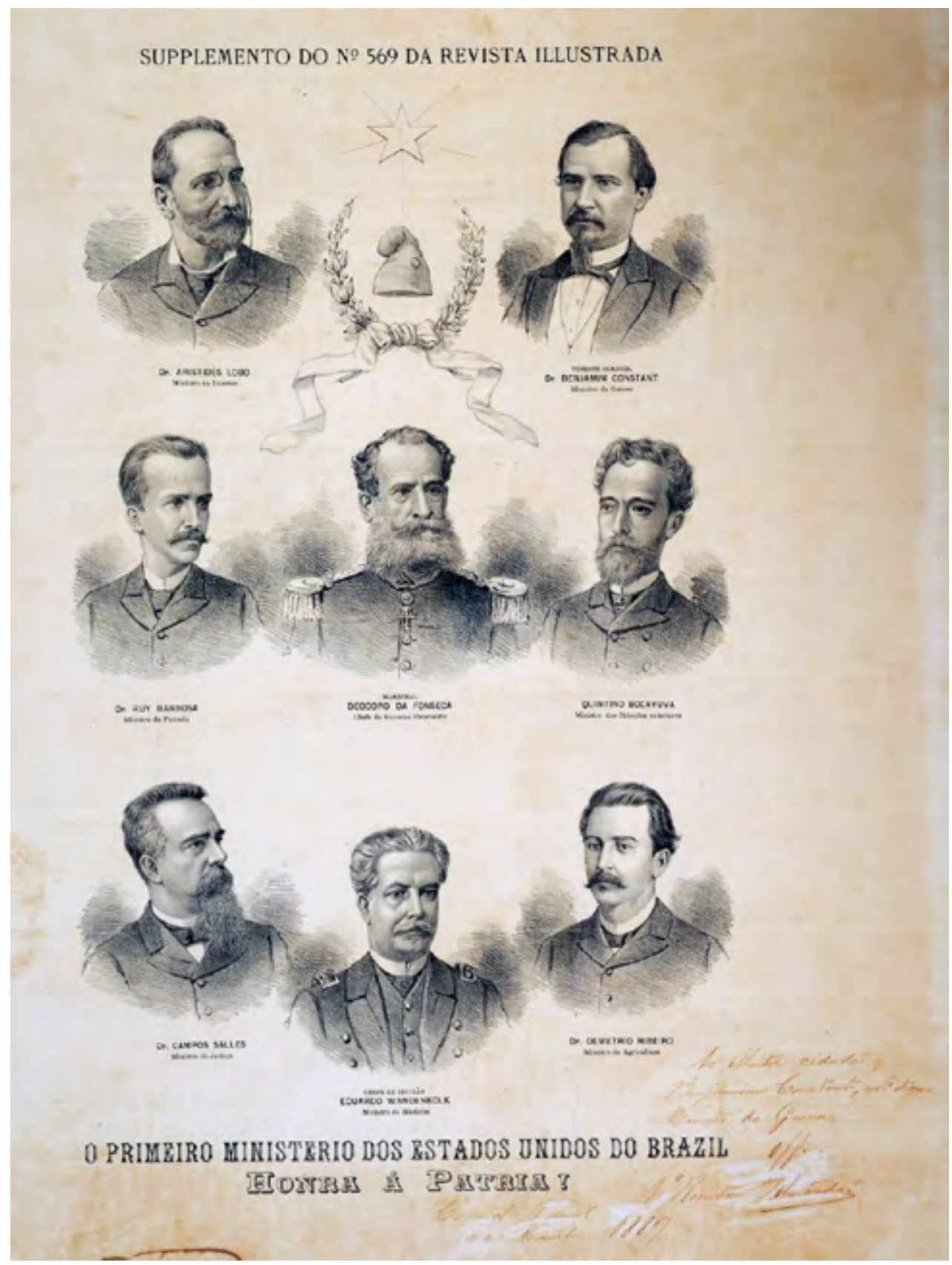

Figura 8. REVISTA ILLUSTRADA. O primeiro ministério dos Estados Unidos do Brazil. 23 de novembro de 1889. Impressão sobre papel, $64 \times 50 \mathrm{~cm}$, Rio de Janeiro. FBC. REG.911. Museu Casa Benjamin Constant, Ibram/MinC.

A imagem de Benjamin foi mobilizada pelos artistas que orbitavam em torno da doutrina de Comte, como Décio Villares e Eduardo de Sá. Os quadros desses artistas eram frequentemente feitos a partir de fotografias, ou as incluíam como figuras dentro das cenas: são metafiguras migrantes e visam organizar o imaginário numa estrutura totalizante e idealista.

As pinturas - ou transfigurações - desses artistas releem a fotografia feita no limiar do advento da República. Na construção de Eduardo de Sá, inverte-se a direção da pose do retratado. Benjamin aparece de corpo inteiro, fardamento militar, retrato da esposa sobre uma mesinha, de um lado, e de outro, livros. O busto de Augusto Comte aparece ao fundo, neste quadro que foi oferecido à municipalidade de Assumpção, no Paraguai, pela Sociedade Benjamin Constant, no âmbito da comissão que buscou repatriar os troféus de guerra obtidos na Guerra da Tríplice Aliança e extinguir as dívidas de guerras paraguaias (LEMOS, 1999, p. 539). 


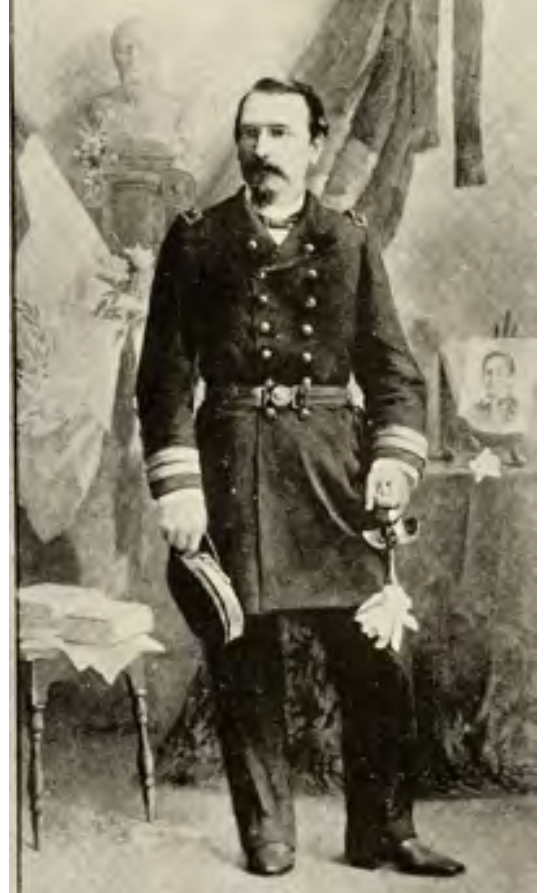

Figura 9. SÁ, Eduardo de. Benjamin Constant. Fundador da Republica no Brazil. Década de 1890. Reprodução fotográfica, impressão sobre papel, $38 \times 25 \mathrm{~cm}$. REG. 910 . Museu Casa Benjamin Constant, Ibram/MinC.

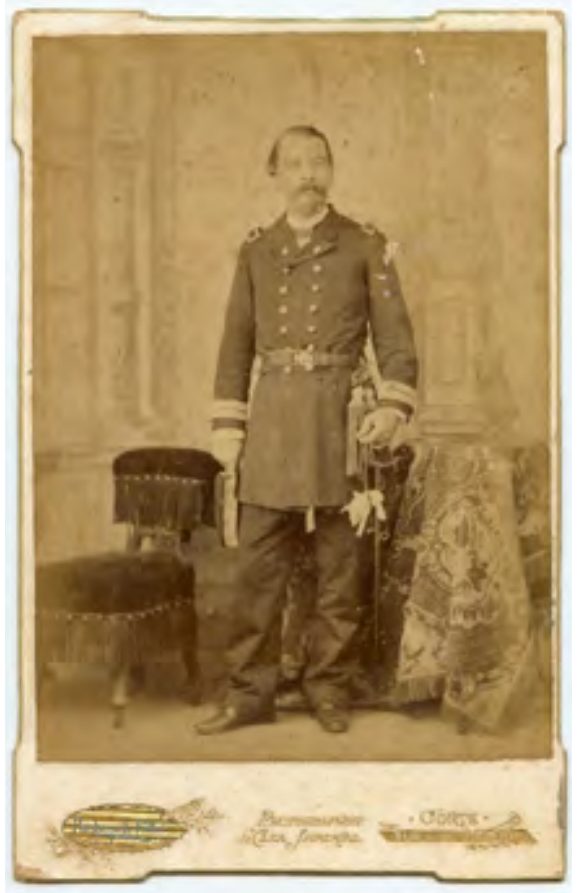

Figura 10. PACHECO E FILHO. Benjamin Constant.

Circa 1889. Carte Cabinêt, albumina, $12 \times 16,5 \mathrm{~cm}$, Rio de Janeiro.

Museu Casa Benjamin Constant, Ibram/MinC.

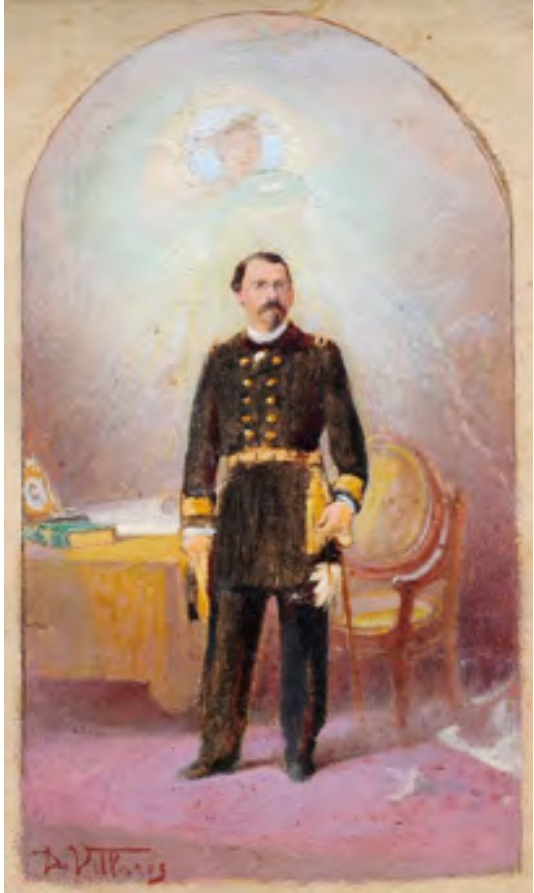

Figura 11. VILLARES, Décio. Benjamin Constant. Óleo sobre tela, $22,5 \times 16,5 \mathrm{~cm}$. REG.302.

Museu Casa Benjamin Constant, Ibram/MinC
$\mathrm{Na}$ versão de Villares, uma pequena composição na qual Benjamin recebe uma espécie de aureola da própria república (ou será Clotilde de Vaux?), vemos a Síntese Subjetiva, de Comte, recebida numa edição de luxo dos alunos da Escola Militar. Sugestão de leitura: Benjamin, militar e professor, sentado à mesa, recebe de Comte a sagrada doutrina, e então levanta-se como guia de um novo tempo, consagrado pela República.

As figuras do positivismo são muito interessantes, sobretudo pelas suas alegorias e sua retórica. Oriundas de um sistema de pensamento cuja epistemologia negava a validade científica de discussões metafísicas, as aparições fantasmáticas que Villares, Sá e outros artistas criaram em suas cenas podem causar estranhamento. Além disso, a produção pictórica desses artistas faz parte de uma mediação de ideias que supera a fotografia como "imagem positivista". Se a fotografia é uma "arte industrial", moderna, objetiva, racional, eminentemente urbana (ROUILLÉ, 2009 , p. 32), o positivismo enquanto movimento político-filosófico e projeto civil lançou mão da fotografia apenas como uma das linguagens possíveis da sua mensagem republicana. Pinturas, fotografias, esculturas convergiam e se interfertilizavam, e quanto recolocam-se todas essas imagens e figuras no circuito da sua circulação, percebe-se que todas podem ser tão positivistas quanto a mais "nítida" e "verdadeira" imagem técnica.

Num tempo de incerteza e instabilidade, a visualidade positivista buscou produzir um tipo ideal de observador, um patriota cuja referência residia numa relação com imagens, e estas, replicando figuras heroicas, olhavam de volta a esse observador, cidadão da crença. Secularizar o Estado, através da separação da Igreja, era o projeto positivista, mas a devoção não poderia ser simplesmente suprimida, algo deveria "tapar os buracos". Para cumprir esse papel, nada melhor que um morto.

\section{O lugar da morte}

Como Benjamin Constant migrou da vida para a história? Terá sido uma estranha coincidência histórica esse passamento de Benjamin e a célebre frase da carta-testamento de Getúlio Vargas, outro positivista, 
em 1954? Toda a retórica em torno do Fundador da República - e as disputas sobre seu papel político se fortaleceu com o seu falecimento. A necessidade de concentrar seus anseios numa imagem forte foi reconhecida pelos positivistas, que aproveitaram para testar publicamente se a ideia comteana de que os vivos são sempre governados pelos mortos poderia garantir o sucesso do seu projeto. Os testemunhos dessa ideia sejam aqueles da cultura visual e material, pois as figuras implicarão sempre numa observação, em alguém que olha enquanto é olhado de volta.

Entramos então no âmbito religioso. Não há espaço aqui para comparar profundamente os traços religiosos do catolicismo e do positivismo - ou para resolver as polêmicas em torno da Religião da Humanidade e suas reedições secularizadas do cristianismo. A proposta é ler as figuras de Benjamin produzidas postumamente como participantes de um tempo de redenção; como reencarnações de outras figuras; como dependentes - e produtoras - de um cidadão da crença. ${ }^{7}$

Seguindo mais uma vez a filosofia de Georges DidiHuberman, os túmulos são objetos que servem para pensar. Teleologicamente, túmulos vazios funcionam como a negação do corpo material, pois que projetam o corpo renovado para a dimensão espiritual e, ao fim, para a eternidade.

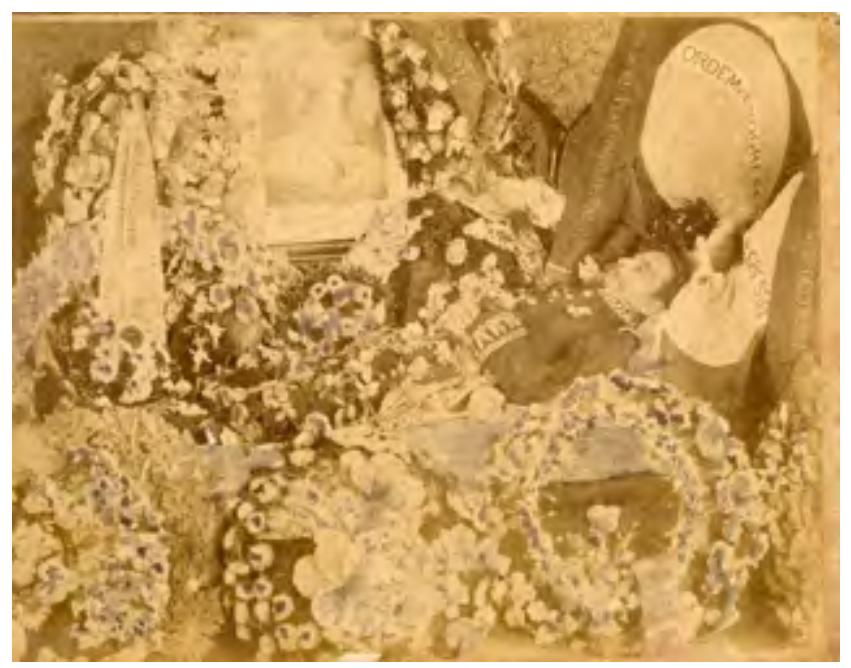

Figura 12. FFEREIRA E ROLTGEN (Photographia Americana). Benjamin Constant em seu leito mortuário. 20 de janeiro de 1891.

Albumina sobre cartão, 21,6×29,7cm, Rio de Janeiro. FBC. F.030. Museu Casa Benjamin Constant, Ibram/MinC.

\footnotetext{
Elisabete Leal, no seu profundo estudo da arte positivista, destaca o conflito que marcou uma tentativa dos positivistas de projetar Benjamin numa celebração fúnebre, impedida de acontecer por pressão da Igreja Católica (LEAL, 2006, p. 209).
}

(...) essa atitude supõe um horror e uma denegação do cheio: como se houvesse aí, nessa tumba, apenas um volume vazio e desencarnado, como se a vida - chamada então de alma - já tivesse abandonado esse lugar decididamente concreto demais, material demais, demasiado próximo de nós, demasiado inquietante em significar algo de inelutável e de definitivo. (...) a vida não estará mais aí, mas noutra parte, onde o corpo será sonhado como permanecendo belo e benfeito, cheio de substância e cheio de vida - e compreende-se aqui o horror do vazio que gera uma tal ficção -, simplesmente será sonhado, agora ou bem mais tarde, alhures (DIDIHUBERMAN, 2010, p. 40-41).

Antes de descer à definitiva sepultura, Benjamin foi velado em casa, no seu "primeiro mausoléu", por assim dizer. ${ }^{8}$ Como aparição e espelhamento do passado, Augusto Comte está presente na cena, também em seu leito de morte. Símbolos da nação envolvem o corpo, junto com flores. Décio Villares pintou a cena a partir da fotografia de Ferreira e Roltgen (Photographia Americana) (Figuras 12, 13). O passamento de Benjamin, que logo viraria Fundador da República, logo encheu seu corpo de nova substância, "permanecendo belo e benfeito", em imagens, evidentemente.

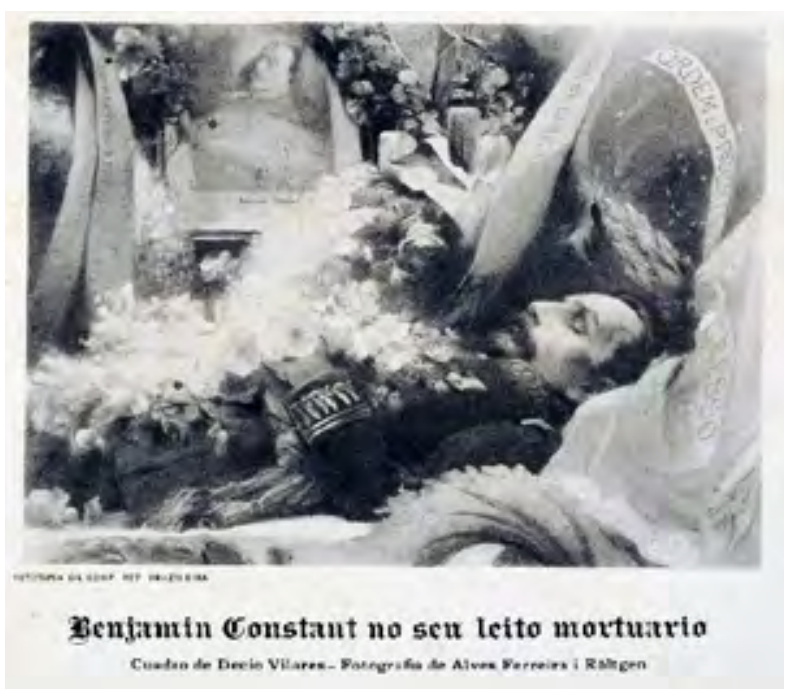

Figura 13. VILLARES, Décio.

Benjamin Constant no seu leito mortuário. Sem data. Reprodução em fototipia, $18,1 \times 22,9 \mathrm{~cm}$, Rio de Janeiro. REG.917. Museu Casa Benjamin Constant, Ibram/MinC.

\footnotetext{
8 Desde as primeiras sugestões de musealização da casa de Benjamin (1891), até o processo de tombamento pelo SPHAN (1958) e a abertura do museu (1982), o prédio foi descrito como o lugar em que "viveu e veio a falecer" Benjamin Constant.
} 


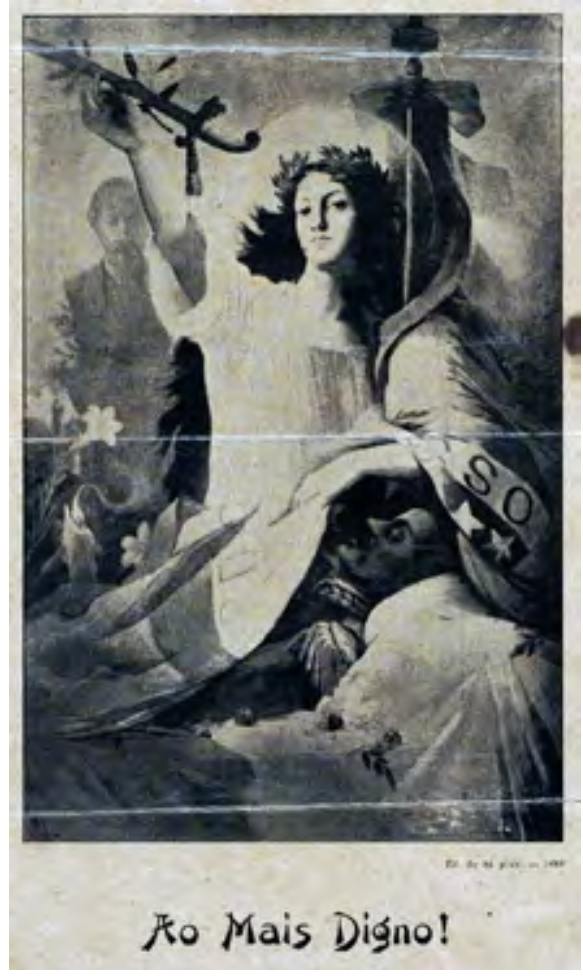

Figura 14. SÁ, Eduardo de. Ao mais digno! 1899. Impressão sobre papel, $37,5 \times 27,5 \mathrm{~cm}$, Rio de Janeiro. REG.906. Museu Casa Benjamin Constant, Ibram/MinC.

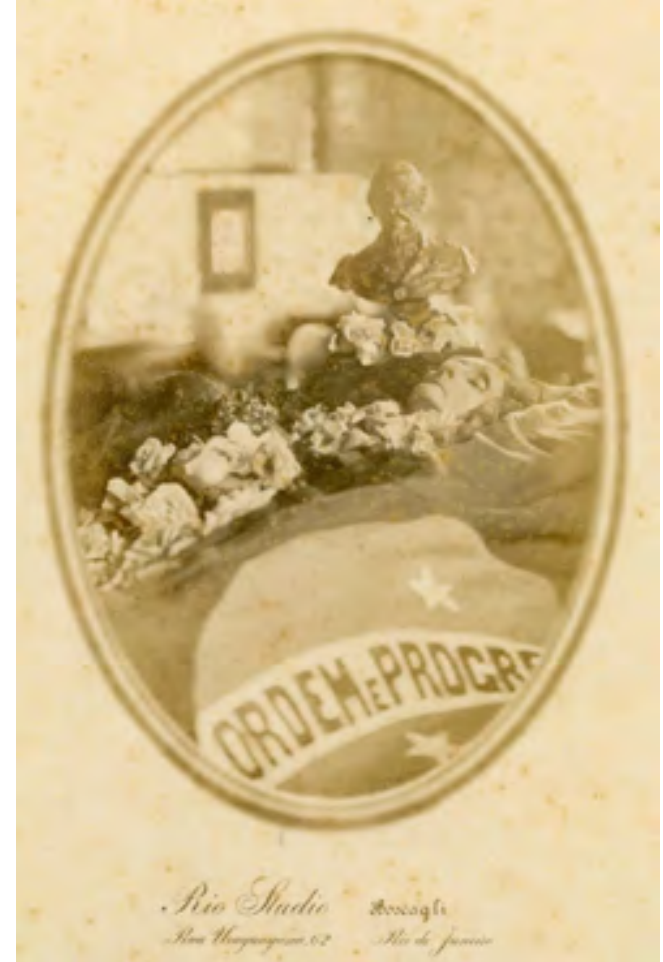

Figura 15. BOSCAGLI \& C. (Rio Studio).

Maria Joaquina Botelho de Magalhães em seu leito mortuário. 1921. Gelatina, $23 \times 16,8 \mathrm{~cm}$, Rio de Janeiro. FBC. F.057. Museu Casa Benjamin Constant, Ibram/MinC.
Não passará muito tempo e lá estará Benjamin ressurreto, novamente de pé. No quadro de Eduardo de Sá, de 1899, ele irá velar Floriano Peixoto, reconciliado com a bandeira nacional. A República o envolve, Benjamin ao fundo, como sombra que o

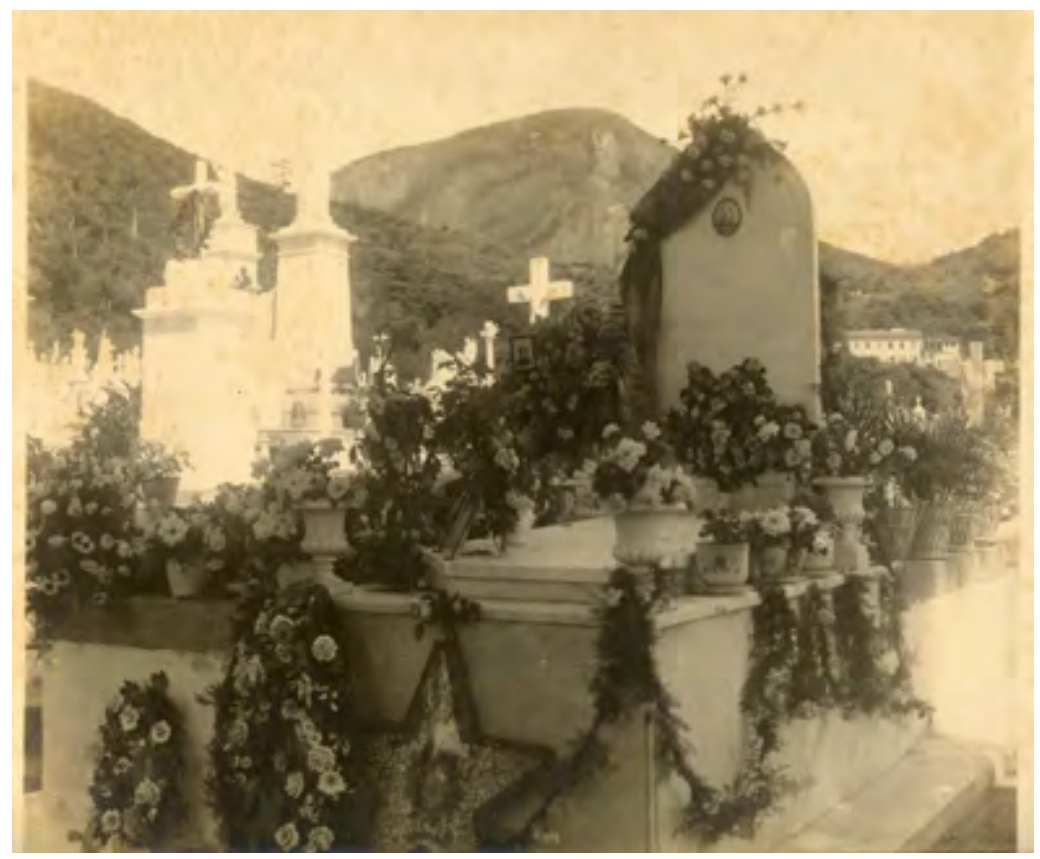

espera. Mas não será só o cadáver de Floriano que Benjamin velará.

Em abril de 1921 falece Maria Joaquina, que havia guardado e cultivada a imagem do marido. Também na casa onde residiram, seu corpo foi velado e, sobre ele, paira o busto duro e sério de Benjamin. Para além da dor familiar e da perda no âmbito privado, qual teria sido o sentido cívico dessas mortes e dessas imagens? Lugar de sacrifício e de culto, da morte e da renovação, a tumba de Benjamin Constant e de Maria Joaquina se oferece ao observador em toda a sua materialidade, pedra, flores e figuras, com a fotografia dos mortos.

Figura 16. BOSCAGLI \& C. (Rio Studio). Sepultura de Benjamin Constant e Maria Joaquina, por ocasião do Culto Cívico, no Club Militar. 1921. Gelatina, $29,5 \times 24,9 \mathrm{~cm}$, Rio de Janeiro. FBC. F. 601 . Museu Casa Benjamin Constant, Ibram/MinC. 
A fotografia registra um dos aspectos do Culto Civico. Effusão Patriotica em memoria de D. Maria Joaquina da Costa Botelho de Magalhães, um evento civil organizado por Manoel Miranda (o mesmo positivista que idealizara, em 1908, o Dia da Bandeira) em 16 de abril de 1921, no Club Militar do Rio de Janeiro, no qual desejava honrar o "egregio par Benjamin Constant e Maria Joaquina - com que a sorte dotou graciosamente a nossa terra". O culto seria, assim, uma oferta à posteridade,

uma prova de que os Brazileiros da actual geração não viram indiferentemente desaparecer dentre os vivos essa preclarissima Senhora, cujo nome honra a Patria e a Humanidade e cuja gloria será eterna porque está ligada conscientemente e apaixonadamente á gloria imorredoura de Benjamin Constant (MIRANDA, 1921, p. 4).

Os altares da cerimônia secular apresentavam biografias visuais: fotos de Maria Joaquina ainda criança, adulta, já viúva e morta, encimadas novamente pelo busto de Benjamin. Em outro vê-se o quadro $A$ Proclamação da República, de Oscar Pereira da Silva, e a figura da República, numa clara conexão

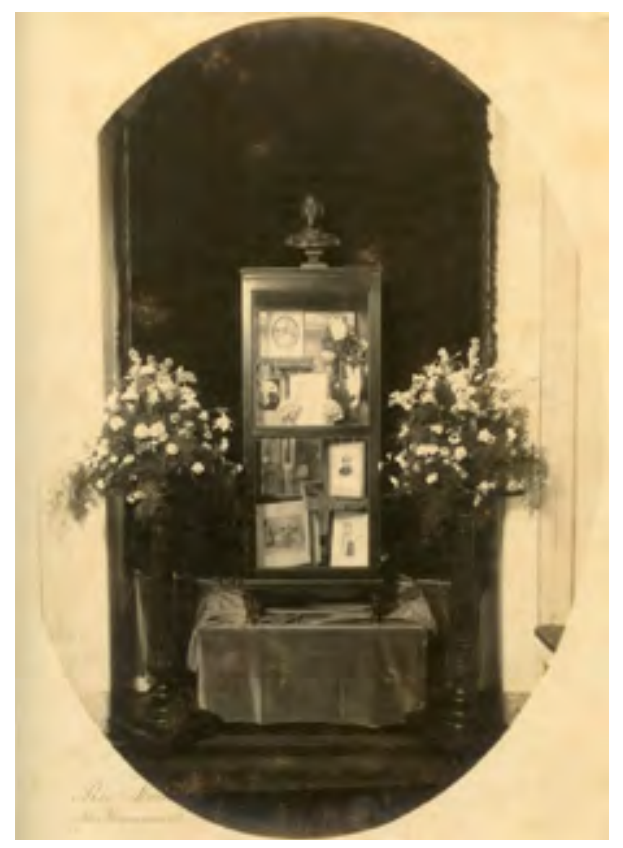

Figura 17. BOSCAGLI \& C. (Rio Studio).

Objetos memorativos da vida de Maria Joaquina Botelho de Magalhães expostos no Culto Cívico, por ocasião do seu falecimento. 16 de abril de 1921.

Gelatina sobre cartão, $29,5 \times 24,5 \mathrm{~cm}$, Rio de Janeiro. FBC. F.600. Museu Casa Benjamin Constant, Ibram/MinC. entre Maria Joaquina e a simbologia feminina cara ao Positivismo. O próprio boletim do evento afirmava que a sua atitude de renúncia, deixando Benjamin partir para o confronto com a monarquia sob o risco de perder o marido foi uma prova de que estava "dominada pelo civismo, colocando a felicidade da Patria acima do seu devotado amor". Concluía que "a sua parte na fundação da Republica foi portanto notável e talvez, dada a harmonia da sua união conjugal, imprescindível" (MIRANDA, 1921, p. 3).

Um outro "altar" foi montado na sala de trabalho de Benjamin, a mesma que abriga seus livros no atual museu. Mas não é como um escritório ordinário que está decorada, na fotografia. Sobre a mesa veem-se as homenagens e presentes recebidos dos alunos da Escola Militar (como a edição de luxo da Síntese Subjetiva, de Comte). Ao fundo, um busto e o quadro de Benjamin, de Décio Villares. Sobre este, uma figura com o busto de Comte. A porta aberta deixa entrar uma luz ofuscante, como a porta da justiça na fábula kafkiana, pela qual ninguém pode passar. Aqui, porém, tudo aponta para a ausência do dono da sala. A cadeira rodada para o lado. Outra vez, seu ocupante já se levantara. Teria saído pela porta, como queriam seus alunos, a conduzir "um povo desgraçado à terra da promissão"?

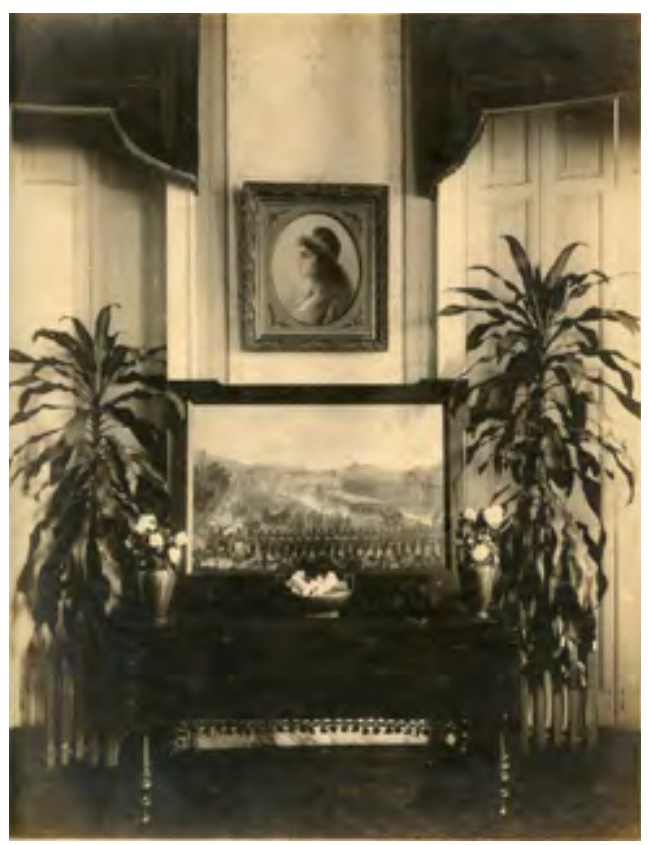

Figura 18. BOSCAGLI \& C. (Rio Studio). Representações da República expostas no Culto Cívico, por ocasião do falecimento de Maria Joaquina Botelho de Magalhães. 16 de abril de 1921.

Gelatina, 22,6×29,4cm, Rio de Janeiro. FBC. F.034. Museu Casa Benjamin Constant, Ibram/MinC. 


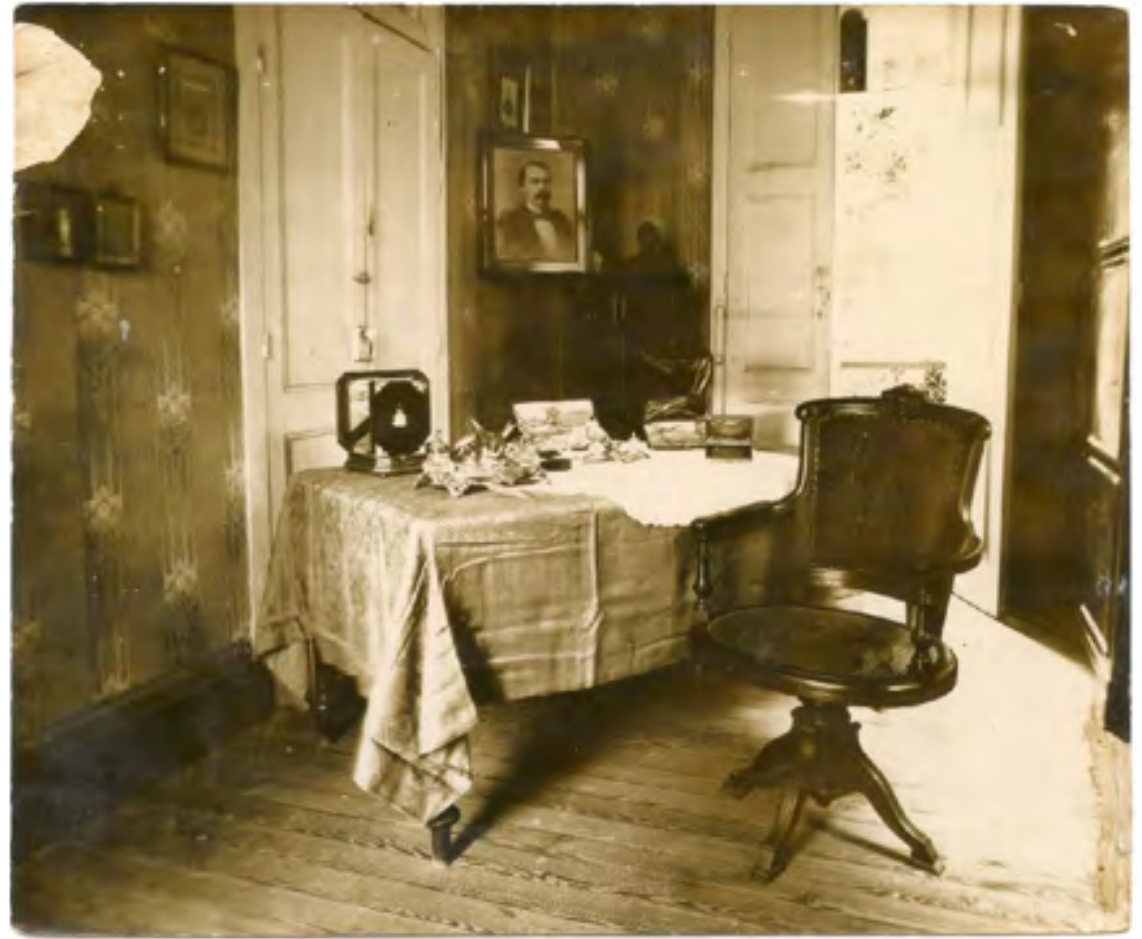

Figura 19. Autoria desconhecida. Gabinete de Benjamin Constant em sua última residência. Sem data. $14 \times 11,5 \mathrm{~cm}$, Rio de Janeiro. FBC. F.558.

Museu Casa de Benjamin Constant, Ibram/MinC.

\section{Conclusão}

Quando se inicia a visita ao Museu Casa de Benjamin Constant, pelo hall de entrada, o primeiro cômodo do lado esquerdo é a sala de trabalho do Fundador da República. Livros, pinturas, objetos pessoais. Ele está ordenado segundo fragmentos de memória e informação visual. O visitante é informado de que se trata do escritório de Benjamin e que replica, com adaptações, seu gabinete no Imperial Instituto dos Meninos Cegos, instituição educacional que dirigiu por vários anos. Como nos conta seu neto, Benjamin Fraenkel, que tinha nítidas lembranças da casa do avô, era ali que Benjamin estudava e trabalhava, quando se mudou para sua última residência, em 1890.

Como se soubesse que precisava produzir um testemunho, Benjamin Constant teve seu gabinete no Instituto fotografado em 1899. Registraram-se seu mobiliário, obras de arte, fotografias nas paredes, arranjos florais, moringas d'água, livros na estante, sobre a mesa, um deles pronto para ser manuseado pelo professor. Essa fotografia é o primeiro fragmento documental no percurso que leva até ao escritório de trabalho experienciado no museu. Nela, o pintor adicionou, aos poucos, os corpos humanos, as cores, as ações. Benjamin já chegara e abrira o livro, que lê em companhia de uma aluna, sua filha Aracy (segundo o relato de seu neto). Enfim, chegamos ao definitivo óleo sobre tela, onde nada mais é fotográfico, a não ser tudo o que serviu de base para a aparição nesse espaço educativo. É esta figura que pende da parede do hall de entrada do museu, como documento e justificativa da expografia que o visitante contempla.

Quantas histórias, intenções, recortes, inclusões e apagamentos num só cômodo de uma casa oitocentista! Como escapar de uma suposta coerência narrativa e explorar essas imaginações contraditórias? Como comunicar esse indizível das aparições fantasmáticas de heróis fabricados?

$\mathrm{O}$ mapeamento de trajetórias das figuras e das imagens que elas materializam é um dos fatores imprescindíveis de uma história visual. Ele permite que os objetos da arte e da cultura material sejam avaliados nas dimensões espaciais e temporais da trama histórica da qual participam. Porém, não podemos assumir uma postura animista: as figuras não têm vontades próprias e não pensam. $\mathrm{O}$ fato de atribuirmos a elas atitudes humanoides é fruto de que toda imagem existe para observação (mesmo as figuras proibidas implicam num observador latente que poderá quebrar o tabu do não-ver). Como os textos verbais, que carregam o fardo do leitor implicado, as imagens e as figuras tem os seus observadores implicados e, além disso, estão sempre prontas olhar de volta, quando são vistas, pois que nós mesmos projetamos nelas os nossos desejos. 

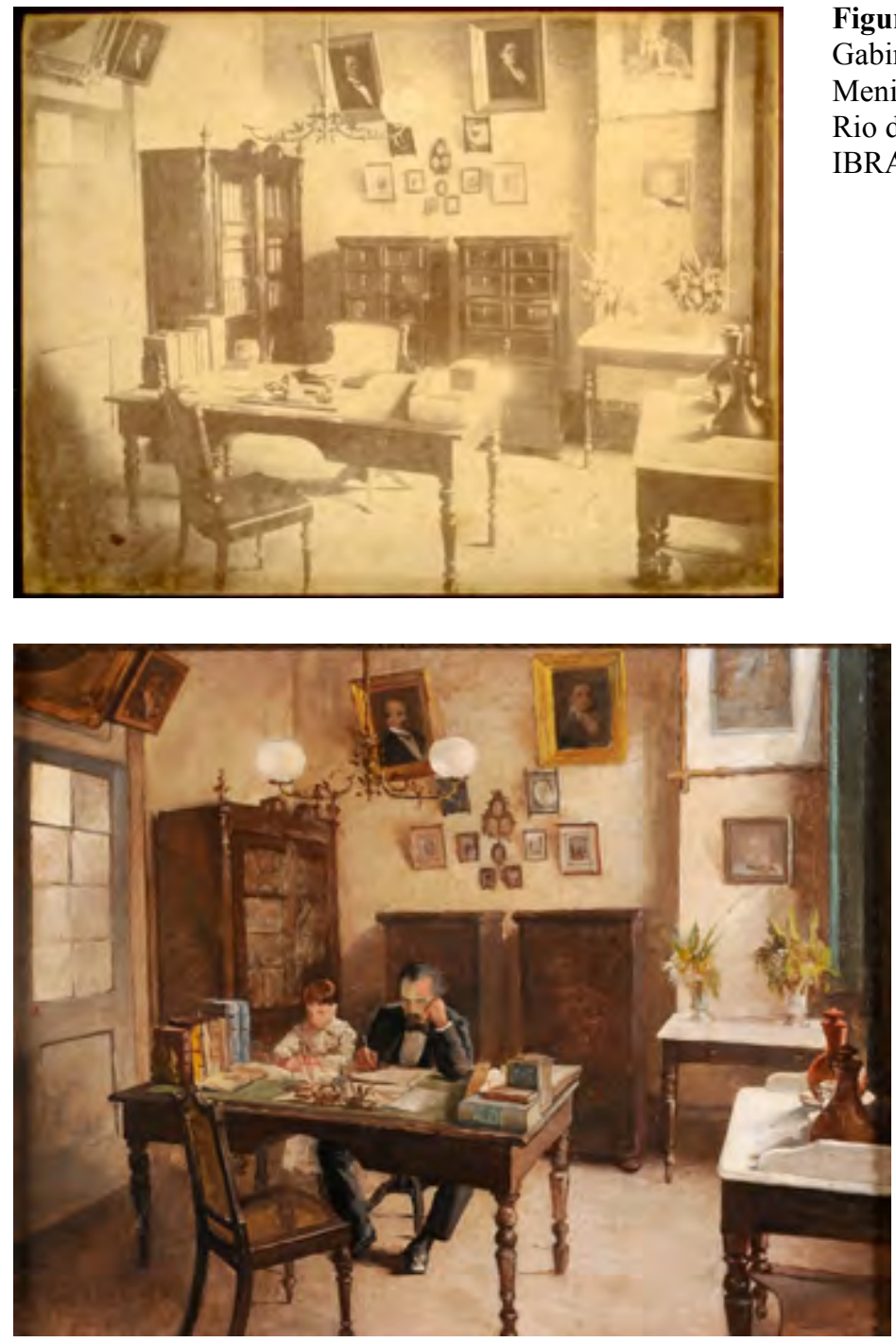

Figura 20. Autoria desconhecida.

Gabinete de Benjamin Constant no Imperial Instituto dos

Meninos Cegos. Circa 1889. Albumina sobre cartão, $30,9 \times 23 \mathrm{~cm}$, Rio de Janeiro. FBC. F020. Museu casa de Benjamin Constant, IBRAM, MinC.

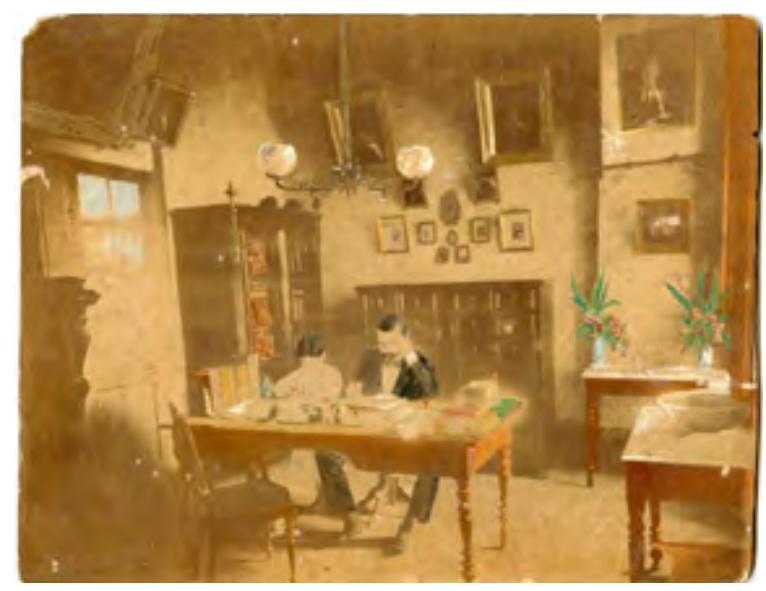

Figura 21. VILLARES, Décio. Benjamin Constant e filha no seu gabinete. Circa 1889. Albumina, fotopintura, $26 \times 20,2 \mathrm{~cm}$, Rio de Janeiro. FBC. F.021. Museu Casa de Benjamin Constant, IBRAM, MinC.

Figura 22. VILLARES, Décio.

Gabinete de Benjamin Constant no

Imperial Instituto dos Meninos Cegos. Circa 1889. Óleo sobre tela, 21,5 x 27,2cm, Rio de Janeiro. REG.046. Museu casa de Benjamin Constant, IBRAM, MinC.
O republicanismo positivista do fim século XIX e princípio do XX buscou construir um observador crente, um cidadão que deve "fazer da experiência do ver um exercício da crença" (DIDI-HUBERMAN, 2010, p. 41). O lugar da morte na retórica positivista é um dos modos de avaliar esse processo. A tumba só tem valor de culto enquanto lugar vazio: deve-se deixar guiar pelo exemplo cidadão dos mortos que, sepultados, erguem-se novamente em fotografias de família, pinturas e monumentos públicos, como phantoms a olhar de volta. É nesse sentido que os vivos são governados pelos mortos. Suas sombras esvaziam os túmulos para encher o espaço social do museu. É nele que ressuscitam esses mortos e que revivem para preencher novamente os cômodos da história.

A imagem fabricada de Benjamin, a despeito das figuras que a tentaram suportar, morreu. Em algum ponto da história da República brasileira, ela esmoreceu e foi sufocada. Ele nunca foi unanimidade. Do primeiro quarteto republicano, está em segundo plano, com Prudente de Moraes, já que Deodoro e Floriano são as figuras históricas mais reconhecidas. Ele perdeu ainda a disputa de memória com Duque de Caxias. Nem todo o esforço positivista para esquadrinhar o local exato onde deveria ficar o monumento a Benjamin Constant foi suficiente para que este mesmo memorial fosse deslocado para dar lugar ao monumento a Caxias, no Rio de Janeiro.

José Murilo de Carvalho chegou a uma concussão semelhante quando afirmou que "falharam os esforços das correntes republicanas que tentaram expandir a legitimidade do novo regime" e que "sem raiz na vivência coletiva, a simbologia republicana caiu no vazio" (CARVALHO, 1990, p. 141). O que resta, então, a uma instituição como o Museu Casa de Benjamin Constant? Seria apenas um prédio que ecoa o vazio? A morte e a morte de Benjamin Constant: está aí uma temática eminentemente republicana e urgente. 
Em 1910, Crisanto Sá de Miranda Pinto procurava uma justa representação da República para presidir seu casamento. É um emblemático caso em que um indivíduo traz para perto de sua vida privada, de seu íntimo, uma imagem política. É fazer de uma figura pública uma testemunha, é incorporar de bom grado e por obediência os valores agregados num homem morto e ressurreto. Hoje, e enquanto a casa for um espaço público de memória, aberto à sociedade, é o contrário o que ocorre. Levam-se as histórias pessoais, os conhecimentos, as dúvidas, as descrenças particulares para um lugar de memória pública. $\mathrm{O}$ que as imagens e figuras de Benjamin Constant estão dizendo em nossos dias? O que elas estão vendo, quando nos observam de volta? Neste momento em que muitos falam na necessidade de refundar a República, por que não indagar o seu Fundador? Quando se ouve da existência de uma "República de Curitiba" que abala a do Planalto Central, e que nem uma nem a outra são Repúblicas com e para o povo, talvez seja uma boa hora de avaliar se as figuras de Benjamin Constant podem ser realmente imagens autênticas, como sugere Walter Benjamin (BENJAMIN, 2006, p. 505): aquelas imagens que nascem, mas que se revelam como iluminações num outro tempo, não entre passado e presente, mas entre um Pretérito e um Agora, para servir como crítica de um momento de crise.

\section{Referências}

BENJAMIN, Walter. Passagens. Tradução e coordenação: Willy Bolle. São Paulo: Imprensa Oficial do Estado/UFMG, 2006.

CARVALHO, José Murilo de. A formação das almas. O imaginário da República no Brasil. São Paulo: Cia. das Letras, 1990.

DIDI-HUBERMAN, Georges. O que vemos. O que nos olha. São Paulo: Editora 34, 2010.

CIDADE DO RIO. Rio de Janeiro, ano 3, n. 274, p. 1, 30/11/1889. Disponível em: <http://memoria.bn.br/docreader/085669/2507>. Acesso em: 14 jun. 2017.
CIDADE DO RIO. Rio de Janeiro, ano 4, n. 154, p. 1, 9/7/1890. 1890a. Disponível em: <http://memoria.bn.br/DocReader/ 085669/2625>. Acesso em: 14 jun. 2017.

CIDADE DO RIO. Rio de Janeiro, ano 4, n. 35, p. 2, 10/ 11/1890. 1890b. Disponível em: <http://memoria.bn.br/Doc Reader/085669/3037>. Acesso em: 14 jun. 2017.

GOVERNO PROVISÓRIO. Constituição da República dos Estados Unidos do Brasil, Disposições Transitórias, Artigo 8o, 24 de fevereiro de 1891.

LEAL, Elisabete. Os filósofos em tintas e bronze: arte, positivismo e política na obra de Décio Villares e Eduardo de Sá. 2006. Tese. (Doutorado em História) - Universidade Federal do Rio de Janeiro, Rio de Janeiro, 2006.

LEMOS, Renato. Benjamin Constant. Vida e história. Rio de Janeiro: Topbooks, 1999.

MAGALHÃES, Benjamin Constant Botelho de. Anotações sobre as bases gerais para a reforma da instrução pública no Brasil. 1890. BC/MIPCT REP. 890.00.00/1, documento 801. Museu Casa de Benjamin Constant, Ibram/MinC.

MIRANDA, Manoel. Culto civico. 1921. FBC/AR Homenagens a Maria Joaquina da Costa Botelho de Magalhães. Museu Casa de Benjamin Constant, Ibram/MinC.

Mitchell, W. J. T. Image Science. Chicago: University of Chicago Press, 2015. <https://doi.org/10.7208/chicago/9780226231501. 001.0001>.

PACTOS DE SANGUE. Documento redigido pelos alunos da Escola Militar aderindo a BC e ao movimento republicano. 1889. BC/procl. REP. 889.11.17/1 P. Sangue, documento 907. Museu Casa de Benjamin Constant, Ibram/MinC.

PINTO, Crisanto Sá de Miranda. Carta a Maria Joaquina Botelho de Magalhães. Rio de Janeiro, 25 de maio de 1910. FBC/ $\mathrm{MJ} /$ Correspondentes MJ910.05.25. Museu Casa de Benjamin Constant, Ibram/MinC.

PATROCÍNIO, José. Algumas palavras. In: Cidade do Rio, Rio de Janeiro, ano 3, n. 286, p. 1, dez. 1889. Disponível em: <http:// memoria.bn.br/DocReader/085669/2555>. Acesso em: 14 jun. 2017.

PRADO, Eduardo. [S., Frederido de]. Fastos da ditadura militar no Brazil. 4. ed. São Paulo/Pernambuco/Paris: Garraux, de Lailhacar \& Cie, 1890. Disponível em: <http://www2.senado.leg.br/bdsf/ handle/id/518725>. Acesso em: 14 jun. 2017.

ROUILLÉ, Andre. A fotografia. Entre documento e arte contemporânea. São Paulo: SENAC, 2009.

TURAZZI, Maria Inez. Quadros de história pátria: fotografia e cultura histórica oitocentista. In: FABRIS, Annateresa; KERN, Maria Lúcia Bastos (Orgs.). Imagem e conhecimento. São Paulo: Edusp, 2006. p. 229-253.

\footnotetext{
Autor/Author:

MARCOS FELIPE DE BRUM LOPES marcos.lopes@museus.gov.br; marcosfblopes@gmail.com

- Pesquisador e Técnico em Assuntos Culturais do Museu Casa de Benjamin Constant, Ibram/MinC. Pesquisador Associado do Laboratório de História Oral e Imagem da Universidade Federal Fluminense LABHOI-UFF. Doutor em História Social pelo Programa de Pós-Graduação em História da Universidade Federal Fluminense. Autor de artigos sobre fotografia e história e da tese de doutorado sobre o fotógrafo austríaco Mario Baldi. Atua também na área de história e museus.

Researcher and Cultural Affairs Officer at the Benjamin Constant House Museum, Ibram/MinC. Associate Researcher of the Laboratory of Oral History and Image of the Fluminense Federal University LABHOI-UFF. PhD in Social History by the Graduate Program in History of the Fluminense Federal University. Author of articles on photography and history and the doctoral thesis on the Austrian photographer Mario Baldi. Works also in the field of history and museums.

Investigador y Técnico en Asuntos Culturales del Museo Casa de Benjamin Constant, Ibram/MinC. Investigador Asociado del Laboratorio de Historia Oral e Imagen de la Universidad Federal FluminenseLABHOI-UFF. Doctor en Historia Social por el Programa de Postgrado en Historia de la Universidad Federal Fluminense. Autor de artículos sobre fotografía e historia y de la tesis de doctorado sobre el fotógrafo austríaco Mario Baldi. También actúa en el área de historia y museos.
} 